\title{
Spiritualitas di Tempat Kerja dan Keterikatan Karyawan
}

\author{
Muhammad Shohib ${ }^{1}$, Cholichul Hadi ${ }^{2}$ \\ Program Doktor Ilmu Psikologi Universitas Airlangga Surabaya \\ Email: ${ }^{1}$ muhammad-ohib@psikologi.unair.ac.id, ${ }^{2}$ cholichul.hadi@psikologi.unair.ac.id
}

\begin{abstract}
Keterikatan karyawan terhadap organisasi menjadi perhatian besar dari praktisi sumber daya manusia. Hal ini dikarenakan keterikatan karyawan telah terbukti memberikan dampak positif terhadap perkembangan perusahaan, kondisi psiklogis karyawan dan kinerja perusahaan. Spiritualitas di tempat kerja menjadi salah satu aspek internal dalam diri karyawan yang memengaruhi kinerja perusahaan. Penelitian ini bertujuan untuk mengetahui pengaruh spiritualitas di tempat kerja terhadap keterikatan karyawan. Penelitian ini menggunakan pendekatan kuantitatif korelasional dengan menggunakan sampel penelitian sebanyak 191 karyawan. Metode pengumpulan data menggunakan skala spiritualitas di tempat kerja yang dikembangkan oleh Ashmos \& Duchon (2000) dan skala keterikatan karyawan yang dikembangkan oleh UWES (Ultrech Work Engagement Scale) dengan regresi linear sebagai analisa data. Hasil penelitian menunjukkan adanya pengaruh yang signifikan spiritualitas di tempat kerja terhadap keterikatan karyawan ( $F=189,431$; sig $=0,000$ ). Variabel spiritualitas memberikan kontribusi sebesar 50,1\% terhadap variabel keterikatan karyawan.
\end{abstract}

KEYWORDS keterikatan karyawan, spiritualitas di tempat kerja

CITATION Shohib, M., Hadi, C. (2020). Spiritualitas di tempat kerja dan keterikatan karyawan. Cognicia, 8, (1). 10-24.

Perbedaan karakteristik yang dimiliki setiap anggota organisasi dapat menjadi faktor kekuatan dan kelemahan untuk tumbuh dan berkembang. Pengelola organisasi mempunyai kewajiban untuk dapat mengelola setiap perbedaan tersebut agar dapat menjadi elemen yang menguatkan organisasi, sehingga dapat mencapai tujuan organisasi. Salah satu ciri adanya kekuatan dalam diri organisasi adalah manakala muncul keterikatan dari para anggotanya (organizational engagement).

Topik keterikatan karyawan terhadap organisasinya telah menjadi fenomena menarik para akademisi dan praktisi sumber daya manusia. Ketertarikan mereka didasari atas berbagai fakta empirik dan teoritik yang berkaitan dengan keterikatan sebagai sebuah topik yang memberikan kontribusi besar dalam perubahan organisasi, lingkungan kerja dan kondisi karyawan, sehingga meskipun teori dasar keterikatan telah muncul di tahun 1990, tema ini berkembang cepat dengan munculnya berbagai temuan empirik dan perluasan teoritik yang menarik.

Setiap organisasi membutuhkan adanya keterikatan yang dimiliki oleh anggotaanggotanya, karena telah banyak bukti empirik yang menyebutkan bahwa keterikatan ini tidak hanya mempunyai dampak positif terhadap organisasi, tetapi juga terhadap 
individu dan kelompok masyarakat di luar organisasi. Keterikatan dapat membantu meningkatkan kinerja dan pertumbuhan organisasi dan dapat dijadikan sebagai strategi yang efektif untuk retensi karyawan. Selain itu, keterikatan dapat menjadi penentu utama dalam keberhasilan perubahan manajemen (Torrington et al, 2011; Swarnalatha \& Prasanna, 2013; Kumar, 2015).

Keterikatan juga membantu meningkatkan kehidupan kerja individu dalam organisasi, mampu menurunkan dan mencegah terjadinya stres kerja, depresi dan burnout, meningkatkan kesehatan dan keselamatan kerja, kepuasan hidup, dan kualitas kerja individu (Kanten \& Sadullah, 2012, Upadyaya, 2016; Makikangas \& Feldt, 2016; Black et al, 2017; Bakker, 2017). Di samping itu, keterikatan juga memberikan kontribusi yang besar terhadap kehidupan lingkungan di luar organisasi, konsumen dan masyarakat (CIPD, 2013; Goh Kiang, 2014; Bernadeta, 2015).

Keterikatan dianggap penting oleh pengelola organisasi dan merupakan topik yang sedang hangat dibahas oleh para peneliti. Keterikatan karyawan merupakan gagasan dalam perilaku organisasi yang menjadi daya tarik besar dalam beberapa tahun terakhir. Para konsultan bisnis juga menyatakan bahwa keterikatan menjadi sebuah konstrak yang diusulkan untuk diperhatikan dan dikembangkan dalam setiap perusahaan agar dapat meningkatkan keuntungan yang akan diperoleh (Gallup Counsulting, 2008; Boston Counsulting Group, 2010; Bain \& Company, 2010). Bahkan, Society for Industrial and Organizational Psychology (SIOP) pada akhir tahun 2016 telah menempatkan tema keterikatan ini pada urutan ke-5 dari 10 tren penelitian dan diskusi oleh para psikolog industri dan organisasi (retrieved 9 Oktober 2017).

Pembahasan keterikatan karyawan senantiasa dikaitkan dengan self determination theory yang mengungkapkan bahwa keterikatan kerja dipengaruhi oleh kondisi internal individu yang berkaitan dengan teori motivasi, kepuasan, dan variabel lain yang relevan secara personal. Spiritualitas dimaknai sebagai sebuah kondisi internal seseorang yang mendorong munculnya perilaku kerja yang positif. Istilah 'spiritualitas' memang sering disalahartikan, dilihat sebagai segi yang konteksnya sama dengan agama, keyakinan tertentu, aturan moral, dan tradisi-tradisi. Ashmos \& Duchon (2000) memberikan pengertian secara lebih sistematis tentang spiritualitas di tempat kerja, yakni pemahaman diri pekerja sebagai makhluk spiritual yang jiwanya membutuhkan 'makanan' berupa pengalaman akan rasa bertujuan dan bermakna dalam pekerjaannya dan mengalami perasaan saling terhubung dengan orang lain di tempat kerja. Dengan spiritualitas di tempat kerja, karyawan lebih memiliki 'nilai' dalam pekerjaan, mengurangi tingkat ketakutan atau stres, hingga mampu berkomitmen tinggi pada pekerjaan.

Berbagai penelitian menemukan bahwa spiritualitas di tempat kerja memiliki dampak langsung terhadap karyawan. Dampak tersebut di antaranya adalah timbulnya hubungan positif yang signifikan dengan kepuasan kerja karyawan, adanya sikap sosial yang lebih positif, lebih empati, dan menunjukkan altruisme yang besar. Mereka juga cenderung untuk merasa lebih puas dengan pekerjaannya (Hassan et al., 2016). Penelitian lain dilakukan oleh John, Andrew, and Jeffery (2003) yang menemukan spiritualitas di tempat kerja berhubungan dengan lima variabel sikap kerja, yaitu kepuasan kerja, keterlibatan kerja, komitmen organsasi, merasakan dukungan organisasi, dan keterlibatan karyawan. Sementara Fatimah (2016) 
menemukan hubungan yang positif antara spiritualitas kerja dengan kesejahteraan psikologis pada para pengajar dan menjadi prediktor terkuat dari kesejahteraan psikologis.

Spiritualitas di tempat kerja menjadi prediktor yang kuat dalam komitmen organisasi, yang meliputi komitmen afektif, komitmen normatif, dan komitmen kontinuan (Wainaina, Iravo and Waititu, 2014). Karyawan yang mengalami stres kerja dapat diatasi dengan menggunakan spiritualitas sebagai model coping-nya untuk menurunkan stres dan depresi (Cand \& koul, 2012; Kumar \& Pragadeeswaran, 2011; Miller at al. 2012 ). Spiritualitas juga memengaruhi kinerja dan produktivitas perusahaan (Fry et. Al, 2011). Jika disandingkan dengan budaya organisasi, spiritualitas mempunyai hubungan yang signifikan pada keterikatan karyawan, di mana dimensi kebermaknaan kerja memiliki hubungan yang kuat dengan dimensi vigor dalam keterikatan karyawan. Hal ini juga disampaikan oleh Singh \& Chopra (2016) bahwa kebermaknaan kerja mempunyai hubungan dengan keterikatan kerja dan ketabahan.

Oleh karena itu, dapat disimpulkan bahwa banyak sekali manfaat atau dampak positif yang diberikan oleh spiritualitas kerja pada karyawan. Selain berhubungan positif dengan kepuasan kerja, sikap kerja, keterlibatan kerja, dan komitmen organisasi, spiritualitas kerja juga membawa dampak positif bagi perilaku karyawan, seperti perilaku sosial lebih positif, empati, dan altruisme yang besar.

Berdasarkan pemaparan di atas, dapat dirumuskan masalah bahwa apakah terdapat pengaruh spiritualitas di tempat kerja terhadap keterikatan karyawan? Adapun tujuan penelitian ini adalah untuk mengetahui pengaruh spiritualitas di tempat kerja terhadap keterikatan karyawan.

\section{Spiritualitas di Tempat Kerja}

Spiritualitas di tempat kerja, menurut Ashmos \& Duchon (2000) adalah suatu pengenalan bahwa karyawan memiliki "kehidupan dalam" yang membutuhkan makanan atau asupan di tempat kerjanya, termasuk rasa memiliki tujuan dan makna dalam pekerjaan mereka. Spiritualitas di tempat kerja memiliki tiga komponen, yaitu kehidupan dalam (inner life), pekerjaan yang bermakna, dan komunitas. Ashmos ingin menekankan bahwa spiritualitas di tempat kerja bukan tentang agama, walaupun orang terkadang mengekspresikan kepercayaan agama mereka di tempat kerja. Banyak orang di tempat kerja merasa butuh menemukan kembali apa yang mereka rawat dalam hidup dan mencoba menemukan pekerjaan yang disukainya. Mereka menginginkan sesuatu yang lebih dalam di kehidupan mereka, lebih dari sekedar rutinitas kerja dan gaji untuk hidup sehari-hari. Dengan workplace spirituality, karyawan juga akan memiliki perasaan saling terhubung dengan adanya keterkaitan satu sama lain dalam komunitasnya di tempat kerja.

Ashmos \& Duchon (2000) membagi spiritualitas di tempat kerja menjadi tiga komponen.

1. Kehidupan batin sebagai identitas spiritual. Memiliki spiritualitas di tempat kerja dapat dimulai dengan memahami bahwa setiap orang memiliki kehidupan lahir maupun batin, dan bahwa kehidupan batin individu mempunyai kebutuhan- 
kebutuhan agar lebih bermakna. Dalam kehidupan batin atau inner life, spiritualitas memberikan ekspresi terhadap sesuatu yang ada dalam diri individu, yaitu dengan perasaan dan kekuatan yang datang dari dalam diri. Hal ini bisa dilakukan dengan mengetahui kedalaman diri dan apa yang suci menurutnya.

2. Makna dan tujuan dalam bekerja. Spiritualitas di tempat kerja menyangkut kerja yang lebih bermakna, keterkaitan antara jiwa (soul) dengan pekerjaan, dan bagaimana mendapatkan perhatian dan pengakuan dari perusahaan. Menyangkut juga tentang penerimaan karyawan untuk selalu ingin terlibat dalam pekerjaan yang memberi makna bagi kehidupan mereka.

3. Perasaan terhubung dan komunitas. Spiritualitas di tempat kerja bukan hanya bagaimana karyawan memenuhi kebutuhan-kebutuhan batin dengan mencari pekerjaan yang bermakna, tetapi juga cara agar seseorang dapat hidup dan terhubung dengan orang lain.

Spiritualitas di tempat kerja dipengaruhi oleh tujuh faktor (Ashmos \& Duchon, 2000). Ketujuh faktor tersebut adalah sebagai berikut.

1. Kondisi komunitas, mencakup penilaian terkait dukungan dari komunitas. Komunitas di sini adalah tempat seseorang mengalami pertumbuhan pribadi yang berharga untuk diri mereka sendiri sebagai individu dan memiliki rasa bekerja sama.

2. Work unit as a community yakni sejauh mana unit kerja memberi semangat dan perhatian.

3. Persepsi dan sikap terhadap nilai-nilai organisasi.

4. Pemaknaan dalam pekerjaan.

5. Inner life, terkait harapan seseorang, kesadaran akan nilai pribadi dan perhatian terhadap spiritualitas.

6. Persepsi yang menjadi penghalang menuju spiritualitas.

7. Tanggung jawab pribadi.

8. Hubungan positif dengan orang lain.

9. Kontemplasi atau perenungan.

Ahmos \& Duchon (2000) membagi faktor spiritualitas di tempat kerja ke dalam tiga kategori level atau tingkatan pandangan individu yang memengaruhi spiritualitas di tempat kerjanya.

1. Individual level atau tingkat individu. Tingkatan ini merupakan penilaian karyawan terhadap sikap, pangalaman, dan dirinya sendiri.

2. Work unit level. Merupakan tingkatan di mana karyawan menilai unit kerja atau divisi mereka, baik dengan mengidentifikasi nilai pada unit kerja, tujuan, dan misi unit kerja, serta seberapa besar unit kerja mendorong terbentuknya spiritualitas di tempat kerja pada karyawan.

3. Organizational level atau tingkat organisasi. Individu menilai dan mengidentifikasi organisasi tempatnya bekerja.

\section{Keterikatan Karyawan}

Awal munculnya konsep keterikatan (engagement) yang ditawarkan oleh Kahn (sebagai bapak keterikatan karyawan) pada tahun 1990 bermula dari konsep kerja oleh 
Goffman (1961). Goffman menawarkan sebuah konsep kerja yang membutuhkan kehadiran atau fokus dari para pekerjanya, sehingga perlu adanya keterikatan dari para pekerja. Konsep kerja Goffman ini dikembangkan oleh Kahn di mana ia tidak hanya membicarakan tentang bagaimana seseorang memiliki fokus terhadap pekerjaan, namun juga terkait dengan konsep kehidupan organisasi secara holistik.

Pada pembahasan yang sama, konsep keterikatan karyawan juga dimunculkan oleh Maslach and Leiter (1997). Ia memposisikan keterikatan karyawan secara berlawanan dengan burn-out, di mana konsep burn-out mewakili kondisi karyawan yang mengalami kelelahan, sinisme, dan in-efisiensi kerja. Konsep keterikatan karyawan ini mendukung gerakan psikologi positif yang dikembangkan pada saat itu, di mana pada konsep ini ditemukan berbagai aspek positif untuk memberikan kesuksesan pada diri individu maupun organisasi yang digambarkan melalui efektifitas, efisiensi, kesejahteraan psikologis, dan produktivitas kerja. Sedangkan konsep burn-out memberikan pandangan psikologis pada kecenderungan area negatif (sakit) yang berdampak pada absensi, kecenderungan untuk meninggalkan organisasi atau pindah organisasi, penurunan produktivitas, dan kepuasan kerja.

Pembicaraan keterikatan ini memunculkan dua buah konsep yang sering digunakan secara bersamaan atau bergantian, yaitu keterikatan kerja (work engagement) dan keterikatan karyawan (employee engagement). Keterikatan kerja mengarahkan perbincangan pada keterikatan seseorang dengan pekerjaannya (mirip dengan komitmen kerja), sedangkan keterikatan karyawan adalah keterikatan dengan organisasi atau perusahaannya (seperti definisi komitmen organisasi). Britt (1999) menggunakan konsep self-engagement (keterikatan diri) sebagai perasaan terlibat pada bentuk tanggung jawab dan komitmen untuk memberikan kinerja individual yang baik.

Kahn (1990) membuat konsepsi keterikatan kerja sebagai anggota organisasi yang melaksanakan peran kerjanya, bekerja dan mengekspresikan dirinya secara fisik, kognitif, dan emosional selama bekerja. Lebih lanjut, Kahn mengatakan bahwa keterikatan adalah konsep multidimensi yang mengarahkan fisik, kognitif, dan emosi ke dalam pekerjaannya. Definisi keterikatan juga diberikan oleh Schaufeli et al (2001) yang menyatakan bahwa keterikatan kerja merupakan bentuk positivitas, pemenuhan kerja dari pusat pikiran yang memiliki dimensi vigor (kemauan untuk investasi tenaga dengan level energi yang tinggi, gigih dan tidak mudah lelah), dedikasi (keterlibatan yang kuat yang ditandai oleh adanya antusiasme, rasa bangga dan inspirasi), dan absorption (keadaan totalitas karyawan yang dicirikan dengan sulitnya seseorang berpisah dari pekerjaannya).

Dalam perkembangan awal teori keterikatan karyawan, ada beberapa teori dasar yang dapat dijelaskan, yaitu:

(1) Self Determination Theory (SDT), dikembangkan pada tahun 1985 oleh Deci and Ryan yang mengungkapkan bahwa pemahaman tentang SDT dapat membantu menjelaskan keterikatan melalui regulasi diri, baik secara internal maupun eksternal, motivasi sekaligus kondisi psikologis dan reaksi perilaku yang muncul (absensi, tindakan proaktif). Motivasi ekstrinsik menggambarkan adanya keinginan untuk mendapatkan reward dan menghindari hukuman, sedangkan 
motivasi intrinsik menggambarkan adanya identifikasi dan integrasi yang dapat membentuk pengaturan diri secara otonom. Dasar dari SDT adalah terpenuhinya kebutuhan kepuasan yang dibentuk melalui adanya kompetensi, otonom, dan relasi.

(2) Social Exchange Theory (SET), yang proses perkembangannya berasal dari teori penguatan (reinforcement) pada tahun 1923 oleh Thorndike dan dikembangkan pula oleh Blau (1964). Pada teori ini, para tokoh menjelaskan bahwa keterikatan karyawan terhadap organisasi dipengaruhi atau tergantung pada sumber daya yang sudah diterima atas hubungan timbal balik antara karyawan dan organisasi (Saks, 2006; Kular et al, 2008; Schaufeli, 2013).

(3) The Job Demand Resources Model (JD-R), dikembangkan oleh Demerouti et al (2001), yang menegaskan bahwa keterikatan karyawan disebabkan oleh dua hal, yaitu sumber daya pekerjaan (job resources) dan stimulasi personal (personal resources). Keterikatan karyawan menimbulkan peningkatan yang positif dalam kinerja perusahaan. Job resources didefinisikan sebagai semua aspek yang berasal dari pekerjaan yang memengaruhi pencapaian tujuan kerja dan dapat menstimulasi perkembangan personal. Personal resources didefinisikan sebagai semua aspek yang berasal dari individu, yang dapat mengontrol kesuksesannya. Penelitian tentang keterikatan karyawan menunjukkan faktor-faktor yang memengaruhi bergantung pada jenis organisasi dan wilayah (negaranya). Di samping itu, disarankan juga agar memperhatikan bentuk intervensi untuk melihat akibat langsung maupun tidak langsung yang ditimbulkannya (Muathe and Kamau, 2016).

Berdasarkan paparan di atas, maka hipotesis dalam penelitian ini adalah adanya pengaruh spiritualitas di tempat kerja terhadap keterikatan karyawan.

\section{METODE PENELITIAN}

Penelitian ini menggunakan pendekatan korelasional kuantitatif dengan subjek sebanyak 190 pekerja di Palang Marah Indonesia Cabang Malang dengan status karyawan tetap. Variabel bebasnya adalah spiritualitas di tempat kerja, yaitu terpeliharanya pemenuhan kebutuhan jiwa sebagai makhluk spiritual, rasa bermakna dalam bekerja, dan perasaan menjadi bagian dari komunitas di tempat kerja. Sedangkan variabel terikatnya adalah keterikatan karyawan, yakni pemenuhan kerja dari pusat pikiran yang memiliki dimensi vigor (kemauan untuk investasi tenaga dengan level energi yang tinggi, gigih, dan tidak mudah lelah), dedikasi (keterlibatan yang kuat yang ditandai oleh adanya antusiasme, rasa bangga dan inspirasi), dan absorption (keadaan totalitas karyawan yang dicirikan dengan sulitnya seseorang berpisah dari pekerjaannya).

Adapun data penelitian diperoleh dari instrumen penelitian menggunakan model pengukuran skala. Skala yang digunakan dalam menilai tingkat spiritualitas di tempat kerja adalah questionnaire yang dikembangkan oleh Ashmos \& Duchon (2000) dengan tujuh faktor spiritualitas di tempat kerja, yaitu kondisi komunitas di tempat kerja berjumlah 9 item dengan $\alpha=0,859$, kebermaknaan kerja berjumlah 7 item dengan $\alpha=0,858$, kehidupan dalam (inner life) berjumlah 5 item dengan $\alpha=0,804$, penghalang kepada spiritualitas berjumlah 6 item dengan $\alpha=0,736$, tanggung jawab pribadi 
berjumlah 2 item dengan $\alpha=0,772$, hubungan positif dengan orang lain berjumlah 3 item dengan $\alpha=0,737$, serta kontemplasi berjumlah 2 item dengan $\alpha=0,689$. Skala ini telah diujikan pada 182 karyawan laki-laki dan 515 perempuan dengan rata-rata usia 43,2 tahun dengan rata-rata telah bekerja dengan organisasi selama 7,9 tahun.

Sedangkan untuk mengukur komitmen organisasi dalam penelitian ini, peneliti menggunakan skala Organizational Commitment Questionnaire (OCQ) Moday, Steers \& Porter (1979) dan dikembangkan oleh Ingarianti (2015). Skala ini memiliki tingkat reliabilitas 0,938. Aspek yang diukur, yaitu kepercayaan yang kuat dari tujuan dan nilai-nilai organisasi, berjumlah 13 item dengan nilai $\alpha=0,828$, kesediaan untuk menggunakan usaha yang sungguh-sungguh atas nama organisasi berjumlah 13 item dengan nilai $\alpha=0,803$, dan keinginan yang kuat untuk mempertahankan keanggotaan dalam organisasi berjumlah 14 item dengan nilai $\alpha=0,897$. Skala ini telah diujikan pada karyawan dengan karakteristik karyawan tetap.

Secara umum, penelitian yang akan dilakukan memiliki tiga prosedur utama. Tahap pertama adalah persiapan. Tahap ini dimulai dari penyusunan proposal penelitian dan melakukan pengalihan bahasa atau translate dari skala yang diadaptasi untuk mengukur masing-masing variabel dalam penelitian. Skala yang sudah dialihbahasakan kemudian disusun kembali membentuk sebuah skala untuk mengukur kedua variabel. Skala yang telah dibentuk kemudian di-try out untuk menguji validitasnya. Try out skala dilakukan kepada seratus orang berstatus karyawan atau pegawai swasta yang sedang bekerja atau memiliki pekerjaan minimal dua tahun. Berdasarkan hasil uji validitas, diperoleh hasil beberapa item yang lolos uji validitas. Item yang lolos uji validitas kemudian disusun kembali membentuk sebuah skala untuk mengukur kedua variabel. Pada tahap ini terdapat beberapa item pada instrumen penelitian yang tereliminasi sehingga yang tersisa adalah item yang valid dari Rhitung > Rtabel, dengan menggunakan Rtabel yaitu 0,30 (Azwar, 2015).

Setelah dilakukan uji skala atau try out pada seratus pegawai swasta, didapatkan hasil sebagai berikut:

Tabel 1. Hasil Try out Skala Spiritualitas di Tempat Kerja

\begin{tabular}{ccccc}
\hline $\begin{array}{c}\text { Nama } \\
\text { Instrumen }\end{array}$ & $\begin{array}{c}\text { Jumlah Item } \\
\text { Awal }\end{array}$ & $\begin{array}{c}\text { Jumlah Item } \\
\text { Valid }\end{array}$ & $\begin{array}{c}\text { Indeks } \\
\text { Validitas }\end{array}$ & $\begin{array}{c}\text { Nilai Reliabilitas } \\
\text { (Alpha) }\end{array}$ \\
\hline $\begin{array}{c}\text { Skala } \\
\begin{array}{c}\text { Spiritualitas } \\
\text { di Tempat } \\
\text { Kerja }\end{array}\end{array}$ & 60 Item & 56 Item & $0,306-0,762$ & 0,960 \\
\hline
\end{tabular}

Berdasarkan hasil uji validitas dan reliabilitas skala spiritualitas di tempat kerja, maka diperoleh hasil sejumlah 4 item yang dinyatakan tidak valid dan harus dihilangkan, yaitu pada faktor rasa terhubung dengan komunitas pada aspek penilaian diri dalam komunitas dengan 1 item (X17) dan aspek penilaian kelompok kerja dengan jumlah 1 item (X40), pada faktor pemenuhan kebutuhan jiwa dengan 1 item (X27), serta faktor nilai positif kelompok kerja dengan 1 item (X44).

Tabel 2. Hasil Try out Skala Komitmen Organisasi 


\begin{tabular}{ccccc}
\hline $\begin{array}{c}\text { Nama } \\
\text { Instrumen }\end{array}$ & $\begin{array}{c}\text { Jumlah Item } \\
\text { Awal }\end{array}$ & $\begin{array}{c}\text { Jumlah Item } \\
\text { Valid }\end{array}$ & $\begin{array}{c}\text { Indeks } \\
\text { Validitas }\end{array}$ & $\begin{array}{c}\text { Nilai Reliabilitas } \\
\text { (Alpha) }\end{array}$ \\
\hline $\begin{array}{c}\text { Skala } \\
\text { Komitmen } \\
\text { Organisasi }\end{array}$ & 40 Item & 37 Item & $0,331-0,833$ & 0,958 \\
\hline
\end{tabular}

Berdasarkan hasil uji validitas dan reliabilitas skala komitmen organisasi, maka diperoleh hasil sejumlah 3 item yang dinyatakan tidak valid dan harus dihilangkan yaitu pada aspek kepercayaan yang kuat dan penerimaan tujuan dan nilai organisasi dengan 2 item (Y1 dan $\mathrm{Y} 2$ ), aspek kesediaan untuk menggunakan usaha yang sungguh-sungguh atas nama organisasi dengan 1 item (Y29).

Tahap berikutnya adalah pengumpulan data. Pada tahap ini, item yang telah lolos uji validitas dan reliabilitas disusun kembali menjadi sebuah skala yang kemudian dibagikan kepada karyawan PMI Kota Malang. Setelah seluruh data diperoleh, tahap selanjutnya adalah tahap analisis. Data yang diperoleh kemudian ditabulasi sesuai dengan norma skala. Data tersebut selanjutnya dianalisis menggunakan program SPSS for windows ver.21 menggunakan teknik korelasi product moment, yaitu untuk menguji hipotesis antara satu variabel independen dengan satu variabel dependen (Sugiyono, 2016). Setelah itu, peneliti membahas keseluruhan hasil analisis tersebut dan terakhir, peneliti mengambil kesimpulan.

\section{HASIL PENELITIAN}

Berdasarkan analisis data yang telah dilakukan, diperoleh gambaran subjek berdasarkan jenis kelamin, usia, masa kerja dan jabatan. Hasil dipaparkan melalui tabel sebagai berikut:

\begin{tabular}{clcc}
\hline & \multicolumn{1}{c}{ Kategori } & Jumlah & Persentase \\
\hline \multirow{3}{*}{ Jenis Kelamin } & Laki-laki & 47 & $51,6 \%$ \\
& Perempuan & 44 & $48,4 \%$ \\
\cline { 2 - 4 } Usia & Total & $\mathbf{9 1}$ & $\mathbf{1 0 0} \%$ \\
\hline \multirow{5}{*}{ Masa Kerja } & Dewasa Awal & 64 & $70,3 \%$ \\
& Dewasa Madya & 27 & $29,7 \%$ \\
\cline { 2 - 4 } & Total & $\mathbf{9 1}$ & $\mathbf{1 0 0} \%$ \\
\hline \multirow{5}{*}{ Jabatan } & 1-5 Tahun & 48 & $52,7 \%$ \\
& 6-10 Tahun & 14 & $15,4 \%$ \\
& $>15$ Tahun & 4 & $4,4 \%$ \\
\cline { 2 - 4 } & Total & 25 & $27,5 \%$ \\
\hline & Kepala Seksi Administrasi & $\mathbf{9 1}$ & $\mathbf{1 0 0} \%$ \\
\hline & Kepala Seksi Pelayanan & 1 & $1,1 \%$ \\
& Kepala TU & 1 & $1,1 \%$ \\
& Staf Administrasi & 1 & $1,1 \%$ \\
& Staf Humas \& Rekrutmen Donor & 3 & $3,3 \%$ \\
& Staf Keuangan & 7 & $7,7 \%$ \\
& Staf Laboratorium & 10 & $11 \%$ \\
& Staf Logistik & 5 & $5,5 \%$ \\
\hline
\end{tabular}




\begin{tabular}{lcc}
\hline Staf Pelayanan & 3 & $3,3 \%$ \\
Staf Pemastian Mutu & 3 & $3,3 \%$ \\
Staf Pengolahan Darah & 3 & $3,3 \%$ \\
Staf Pengujian Darah & 7 & $7,7 \%$ \\
Staf Pengujian Mutu & 1 & $1,1 \%$ \\
Staf Urusan Alat \& Kalibrasi & 1 & $1,1 \%$ \\
Staf Karantina \& Distribusi & 5 & $5,5 \%$ \\
Staf Konseling Donor & 1 & $1,1 \%$ \\
Litbang & 1 & $1,1 \%$ \\
Staf Urusan Pengambilan Darah & 14 & $15,4 \%$ \\
Staf Urusan SIM & 1 & $1,1 \%$ \\
Staf Kepegawaian & 15 & $16,5 \%$ \\
\hline Total & $\mathbf{9 1}$ & $\mathbf{1 0 0} \%$ \\
\hline
\end{tabular}

Berdasarkan tabel 3, dapat dilihat bahwa subjek dalam penelitian ini lebih didominasi oleh karyawan laki-laki dibandingkan dengan karyawan perempuan. Hal tersebut ditunjukkan dari persentase subjek laki-laki sebesar 51,6\% di mana jumlah tersebut lebih besar dibandingkan persentase karyawan perempuan yang hanya sebesar $48,4 \%$. Kemudian dari segi usia, lebih didominasi oleh usia dewasa awal sebesar 70,3\% dibandingkan dengan usia dewasa madya dengan persentase $29,7 \%$. Dilihat dari masa kerja subjek, subjek yang bekerja 1-5 tahun lebih mendominasi dengan jumlah 48 orang atau sebesar 52,7\%, 6-10 tahun berjumlah 14 orang atau sebesar $15,4 \%$, 11-15 tahun berjumlah 4 orang atau sebesar $4,4 \%$, dan karyawan yang telah bekerja selama lebih dari 15 tahun berjumlah 25 orang atau 27,5\%.

Tabel 4. Deskripsi Spiritualitas di Tempat Kerja dan Komitmen Organisasi Berdasarkan Data Demografis

\begin{tabular}{clcccccc}
\hline & & \multicolumn{3}{c}{ Spiritualitas di Tempat } & \multicolumn{3}{c}{ Komitmen Organisasi } \\
\cline { 3 - 8 } & & Kerja & Mean & SD & N & Mean & SD \\
\cline { 3 - 8 } Jenis & Laki-laki & 47 & 255,09 & 22,76 & 47 & 149,32 & 17,2 \\
Kelamin & Perempuan & 44 & 218 & 26,13 & 44 & 143,5 & 19,48 \\
\hline \multirow{2}{*}{ Usia } & Dewasa Awal & 63 & 216,21 & 23,569 & 63 & 141,68 & 16,531 \\
& Dewasa Madya & 28 & 233,93 & 22,604 & 28 & 157,36 & 18,353 \\
\hline \multirow{2}{*}{ Masa } & 1-5 Tahun & 48 & 216,65 & 21,4 & 48 & 141,42 & 14,45 \\
Kerja & 6-10 Tahun & 14 & 212,93 & 29,29 & 14 & 141,36 & 20,27 \\
& 11-15 Tahun & 4 & 237,25 & 14,57 & 4 & 153,75 & 11,79 \\
& >15 Tahun & 25 & 236,68 & 22,17 & 25 & 160 & 18,81 \\
\hline
\end{tabular}

Berdasarkan tabel di atas diketahui bahwa mean dari kategori spiritualitas di tempat kerja dilihat dari segi jenis kelamin, subjek laki-laki lebih mendominasi. Nilai mean dari kategori komitmen organisasi juga didominasi oleh subjek laki-laki. Selain itu, subjek yang tergolong dalam usia dewasa madya yaitu usia 41-55 tahun memiliki nilai mean dari spiritualitas di tempat kerja lebih tinggi dibandingkan dengan subjek yang dikategorikan ke dalam usia dewasa awal. Hal ini juga berlaku pada nilai mean dari komitmen organisasinya, di mana subjek yang tergolong ke dalam usia dewasa 
madya lebih dominan dibandingkan subjek yang tergolong usia dewasa awal. Selanjutnya dilihat dari masa kerja, subjek yang telah bekerja selama 11-15 tahun memiliki nilai mean yang lebih dominan dibandingkan dengan masa kerja yang lain, bahkan nilai tersebut lebih tinggi dibandingkan subjek yang telah bekerja selama lebih dari 15 tahun. Namun jika dilihat dari nilai mean dari komitmen organisasinya, subjek yang telah bekerja lebih dari 15 tahun justru memiliki nilai mean yang lebih dominan dibandingkan dengan subjek yang telah bekerja kurang dari 15 tahun.

Untuk mengetahui normal atau tidaknya data, peneliti melakukan uji kenormalan data atau uji normalitas melalui kolmogorov-smirnov dengan menggunakan aplikasi SPSS versi 21. Data dapat dikatakan normal atau berdistribusi normal jika uji kolmogorov-smirnov (asymp sig. 2-tailed) lebih besar dari 0,05 (Trihendradi, 2010). Berdasarkan uji normalitas yang telah dilakukan, diketahui bahwa nilai asym (sig. 2tailed) pada data adalah 0,57 >0,05 dan nilai signifikannya sebesar 0,784 >0,05, maka dapat dikatakan data berdistribusi normal sehingga uji hipotesis dapat dilakukan melalui uji korelasi.

Tabel 5. Uji Hipotesis Product Moment pada Variabel Spiritualitas di Tempat Kerja dan Komitmen Organisasi

\begin{tabular}{cccccc}
\hline $\begin{array}{c}\text { Koefisien } \\
\text { Korelasi (r) }\end{array}$ & $\begin{array}{c}\text { Koefisien } \\
\left.\text { Determinasi ( } \mathbf{r}^{2}\right)\end{array}$ & Sig/p & Ket. & Kesimpulan & $\mathbf{N}$ \\
\hline 0,913 & 0,784 & 0,000 & $\mathrm{p}<0,01$ & Signifikan & 91 \\
\hline
\end{tabular}

Berdasarkan hasil uji korelasi pada tabel 5, diketahui bahwa $(r=0,913 ; p=0,000)$, $(\mathrm{p}<\alpha)$. Kedua variabel dapat dikatakan berhubungan jika nilai $(\mathrm{p}<\alpha)$ dan tanda positif menunjukkan arah hubungan searah yang diartikan jika salah satu variabel tinggi atau naik, maka variabel lainnya juga tinggi atau ikut naik yang ditandai dengan nilai koefisien korelasi (r) berada di antara 0 dan 1 (Trihendradi, 2010). Dalam penelitian ini, dapat diketahui bahwa nilai signifikansi $(\mathrm{Sig} / \mathrm{p})=0,000$ menunjukkan bahwa lebih rendah dari taraf signifikansi $(\alpha)$ yang digunakan yaitu 0,01 atau $1 \%$. Hasil tersebut menunjukkan bahwa terdapat hubungan yang signifikan antara spiritualitas di tempat kerja dengan komitmen organisasi yang ditunjukkan oleh adanya korelasi yang positif dengan angka korelasi 0,913, yang dapat diartikan bahwa apabila spiritualitas di tempat kerja tinggi, maka komitmen organisasi pada karyawan juga tinggi. Begitu pula sebaliknya, apabila spiritualitas di tempat kerja dirasa rendah, maka komitmen karyawan terhadap organisasi juga akan rendah. Selain itu, spiritualitas di tempat kerja juga memberikan kontribusi terhadap komitmen organisasi sebanyak $78,4 \%$ yang artinya menyisakan $21,6 \%$ faktor lain yang memengaruhi komitmen organisasi.

\section{DISKUSI}

Berdasarkan analisis sttistik yang telah dilakukan, koefisien korelasi antara spiritualitas di tempat kerja dengan komitmen organisasi menggunakan product moment menunjukkan adanya korelasi positif antara spiritualitas di tempat kerja dengan komitmen organisasi pada karyawan. Hasil statistik pada penelitian ini menunjukkan nilai koefisien korelasi $(r)=0,913$ dan nilai probabilitas $(p)=0,000<0,01$, sehingga dapat disimpulkan bahwa terdapat hubungan yang signifikan antara 
spiritualitas di tempat kerja dengan komitmen organisasi pada karyawan PMI Kota Malang. Hal ini juga membuktikan bahwa hipotesis yang menyatakan bahwa ada hubungan positif antara spiritualitas di tempat kerja dengan komitmen organisasi dapat diterima.

Ditinjau dari segi usaia, spiritualitas di tempat kerja dan komitmen organisasi pada subjek usia dewasa awal lebih rendah jika dibandingkan dengan subjek usia dewasa madya. Menurut Super (dalam Siska, 2012), individu yang berada pada usia 18-21 tahun adalah masa di mana individu mulai mengkhususkan pilihan pekerjaannya atau mencari perguruan tinggi yang sesuai dengan spesifikasi mereka. Usia 22-24 tahun adalah masa pemantapan bagi individu yang ditandai dengan mulai masuknya individu ke dalam sebuah pekerjaan yang sesuai dengannya, sehingga ia cenderung bekerja keras dalam mencari tempat bekerja yang cocok dan mempertahankan pekerjaannya. Pada usia 25-30 tahun, individu mulai merasa nyaman dengan pekerjaannya sehingga akan berusaha mempertahankan pekerjaannya. Pada usia 31-44 tahun, keamanan dan kenyamanan merupakan hal yang menjadi tujuan utama individu dalam bekerja. Usia 45-59 tahun adalah masa di mana individu telah menetapkan pilihan pada satu bidang karir dan menekuni atau memeliharanya. Sehingga jika dilihat dari segi perkembangan usia, pada usia dewasa madya (40-60 tahun) adalah masa spiritualitas berkembang, di mana individu lebih mengenal pekerjaannyasehingga dapat menghasilkan inovasi-inovasi terbaru. Sedangkan pada masa dewasa awal, individu cenderung belum menemukan makna dari pekerjaannya sehingga terdapat kecenderungan rendahnya komitmen terhadap organisasi.

Komponen-komponen spiritualitas di tempat kerja dalam diri seseorang berkontribusi secara nyata terhadap konstruk perilaku kerja individu. Komponen pekerjaan yang bermakna dan perasaan terhubung dengan komunitas memunculkan komitmen terhadap organisasi di mana individu bekerja, memperkecil keinginan individu untuk keluar dari pekerjaan, memunculkan kepuasan kerja intrinsik, keinginan untuk terlibat dalam pekerjaan, dan meningkatkan harga diri individu. Komponen penegakan nilai-nilai juga memunculkan kepuasan kerja intrinsik pada individu dan memperkecil intensinya untuk keluar dari tempat kerja (Milliman, Czaplewski, dan Ferguson, 2003).

Karyawan yang memiliki spiritualitas di tempat kerja lebih besar akan merasakan bahwa dirinya turut terlibat dalam pekerjaannya. Jika ia dapat mempersepsikan hubungan nilai dalam diri dan organisasinya, serta merasakan makna hidup melalui pekerjaannya, maka karyawan tersebut akan menemukan makna penting dari pekerjaannya. Secara psikologis, ia akan turut menghargai karyawan lainnya. Nilai spiritual organisasi dan nilai spiritual dalam diri individu menjadi prediktif yang positif, interaksi keduanya menghasilkan keinginan bagi karyawan untuk terlibat dalam pekerjaan yang lebih besar (Kolodinsky, dkk., 2008).

Kesesuaian antara nilai yang dimiliki karyawan dengan spiritualitas organisasi yang kuat, akan menghasilkan perilaku yang lebih positif. Karyawan yang menerapkan dan menyertakan nilai spiritualitas seperti keterbukaan, keterhubungan, kebenaran, pertumbuhan dan perkembangan personal, berbagi dan membantu, serta 
menemukan makna dan tujuan dalam pekerjaannya akan mengidentifikasikan organisasinya lebih dekat (Kolodinsky, dkk., 2008).

Berdasarkan penelitian yang dilakukan Amalia \& Yunizar (2000), spiritualitas di tempat kerja berpengaruh secara positif dengan perilaku kerja karyawan. Spiritualitas yang baik menyebabkan sikap kerja yang baik pula. Komponen-komponen spiritualitas di tempat kerja memiliki pengaruh yang positif terhadap kepusan kerja intrinsik, keinginan karyawan untuk keluar, terlibat dalam pekerjaan, dan organizationbased self-esteem (OBSE) atau rasa dihargai oleh organisasi. Secara positif, hal-hal tersebut berpengaruh terhadap komitmen organisasi pada karyawan.

Rego \& Cunha (2007) melakukan penelitian terkait pengaruh spiritualitas di tempat kerja terhadap komitmen organisasi. Hasil penelitiannya menunjukkan bahwa karyawan yang merasakan spiritualitas di tempat kerjanya cenderung mengembangkan komitmen afektif dan normatif yang tinggi, sedangkan komitmen keberlanjutannya rendah.

Di sisi lain, komitmen organisasi juga akan memengaruhi sikap kerja dan produktivitas karyawan. Karyawan dengan komitmen organisasi yang tinggi akan menghasilkan performa yang baik dalam bekerja dan rendahnya intensi untuk absen atau melakukan turnover. Maka karyawan yang memiliki komitmen organisasi yang tinggi akan memiliki produktivitas yang tinggi pula (Luthans, 2002). Sebaliknya, komitmen karyawan yang rendah akan berdampak negatif bagi dirinya maupun organisasi. Karyawan yang memiliki komitmen organisasi yang rendah tidak akan memberikan kemampuan terbaiknya dan dengan mudah keluar dari organisasi tempatnya bekerja (Riady, 2003).

Kontribusi spiritualitas di tempat kerja terhadap komitmen organisasi pada karyawan PMI Kota Malang sebesar 83,3\%, yang artinya menyisakan 17,7\% faktor lain yang memengaruhi komitmen organisasi. Hal ini sesuai dengan penelitian sebelumnya di mana terdapat hubungan timbal balik searah yang terjadi antara spiritualitas di tempat kerja dengan komitmen organisasi, di mana organisasi yang memenuhi kebutuhan spiritualitas karyawannya dengan baik, maka akan mendapatkan komitmen yang baik pula (Rego. A \& Cunha. M.P, 2008).

\section{SIMPULAN DAN IMPLIKASI}

Berdasarkan hasil penelitian, dapat disimpulkan bahwa hipotesis diterima, yang artinya terdapat hubungan antara spiritualitas di tempat kerja dengan komitmen organisasi pada karyawan PMI Kota Malang ( $r=0,913 ; \mathrm{p}=0,000<0,01)$. Hasil tersebut dapat diartikan bahwa semakin tinggi spiritualitas di tempat kerja, maka semakin tinggi pula komitmennya terhadap organisasi, begitu pula sebaliknya.

Implikasi dari penelitian ini di antaranya:

1. Karyawan PMI Kota Malang

Dengan memahami dan mencari makna kerja, menciptakan komunitas di lingkup pekerjaan, dan memahami serta menerima nilai dalam organisasi, akan menciptakan rasa nyaman, rasa menemukan tujuan dalam hidup di samping sekadar rutinitas bekerja, sehingga semakin dekat dengan organisasi, lebih memahami organisasi dan tidak ada rasa terbebani dalam bekerja.

2. PMI Kota Malang 
Dengan mempertahankan dan memfasilitasi karyawan untuk terus menemukan makna dari pekerjaan, rasa menjadi bagian dari komunitas di tempat kerjanya, serta merasa sesuai dengan nilai yang ada pada organisasi, maka akan membuat karyawan semakin ingin terlibat secara penuh dalam pekerjaan. Hal ini membuat komitmennya terhadap organisasi semakin meningkat sehingga karyawan menjadi lebih produktif dalam bekerja.

3. Peneliti selanjutnya

Bagi peneliti selanjutnya, diharapkan penelitian ini dapat dijadikan referensi, inspirasi atau wawasan untuk melakukan penelitian serupa maupun pengembangan penelitian.

\section{REFERENSI}

Allen, N.J and Meyer, JP (1997). Commitment in the Workplace; Theory, Research, and Application. SAGE Publications: Thousand Oaks, London, New Delhi.

Ali and Ikhlas (2014). Employee Engagement and Organizational Commitment: Evidence from Jordan. International Journal of Business, 19(2).

Ashmos, D. P., and Duchon, D (2000). Spirituality at Work: A Conceptualization And Measure. Journal of Management Inquiry, 9(2), 134-145. Journal Of Business $\mathcal{E}$ Economics Research-August, 2009 Volume 7, Number 846.

Bogy .J, (2014). Hubungan Antara Komitmen Organisasi dengan Organizational Citizenship Behavior (OCB). Naskah Publikasi; Universitas Muhammadiyah Surakarta.

Chand, P. \& Koul H. (2012) Workplace Spirituality, Organizational Emotional Ownership and Job Satisfaction as Moderators in Coping with Job Stres. International Conference on Humanities, Economics and Geography (ICHEG'2012)

Dehaghi, M. R., Goodarzi, M., \& Arazi, Z.K. (2012). The effect of spiritual value on employees' organizational commitment and its models. Procedia Social and Behavioral Sciences, 62, 159-166.

Fatimah (2016). Spiritualitas Kerja (Spirituality At Workplace) Dan Trait Neuroticsm Sebagai Prediktor Kesejahteraan Psikologis (Psychological Wellbeing) Pada Pengajar Sekolah Luar Biasa (SLB) Di Daerah Istimewa Yogyakarta. Publikasi Skripsi: Universitas Islam Negeri Yogyakarta.

Fry, L. W., Hannah, S. T., Noel, M., \& Walumbwa, F. O. (2011). Impact of spiritual leadership on unit performance. The Leadership Quarterly, 22(2), 259-270.

Hassan Et.al (2016). Impact Of Workplace Spirituality On Job Satisfaction: Mediating Effect Of Trust. Cogent Business \& Management, 3: 1189808

Ingarianti (2015). Pengembangan Alat Ukur Komitmen Organisasi. Jurnal RAP UNP, Vol. 6, No. 1.

Jessica \& Eddy (2014). Hubungan Budaya Organisasi dan Komitmen Organisasi pada Kinerja Karyawan. Trikonomika Vol.13, No.2, Desember 2014

Kreitner, Robert and Kinicki, Angelo (2005). Perilaku Organisasi. Edisi 9 Jilid 1, Jakarta: Salemba Empat. 
Kumar, T., \& Pragadeeswaran, S. (2011). Effects of Occupational Stres on Spiritual Quotient Among Executives. International Journal of Trade, Economics and Finance, 2(4).

Memari, N. dkk (2013). The impact of Organizational Commitment on Employees Job Performance. Interdiciplinary Journal of Contemporary Research In Business.

Miller, L., Wickramaratne, P., Gameroff, M. J., Sage, M., Tenke, C. E., \& Weissman, M. M. (2012). Religiosity and major depression in adults at high risk: a ten-year prospective study. American Journal of Psychiatry, 169(1), 89-94.

Milliman J, Andrew J. Czaplewski and Jeffery Ferguson (2003). Workplace Spirituality and employee work attitudes. Journal of Organizational Change Management Vol.16 No.4; Collage Business, University of Colorado, Colorado Springs, Colorado, USA.

Moorhead, Gregory dan Ricky W. Griffin (2013). Perilaku Organisasi. Jakarta: Salemba Empat.

Mowday, Steers and Porter (1979). The Measurement of Organizational Commitment. Journal of Vacational Behavior 14, 224-247.

Overell, S, (2008). Inwardness: The rise of meaningful work. The work foundation. Provocation Series, 4(2).

Pooja Garg \& Renu Rastogi (2009). Effect of Psychological Wellbeing on Organizational Commitment of Employees. The Icfai University Journal of Organizational Behavior, Vol. VIII, No.2, 2009.

Rahadyan \& Andika (2008). Pengaruh Komitmen Organisasional Dan Profesional Terhadap Kepuasan Kerja Auditor Dengan Motivasi Sebagai Variabel Interventing (Studi Empiris Pada Kantor Akuntan Publik Di Semarang). Jurnal Bisnis dan Ekonomi (JBE), Hal. 80-90, Vol.5; Universitas Stikubank Semarang.

Rego, A \& Cunha, M.P (2008). Workplace Spirituality and Organizational Commitment: An Empirical Study, Journal of Organizational Change Management Vol.21 No.1, 2008; Emerald Group Publishing Limited.

Riyanto, Supriyanto and Ali (2017). The influence of workplace spirituality and organizational culture on employee engagement of Y generation in PT. Krama Yudha tiga Berlian Motors (KTB). The international journal of social science and humanities invention 4 (7) : 3598-3606, ISSN : 2349-2031

Robbins dan Judge, (2008). Perilaku Organisasi, Jilid 1, Salemba Empat, Jakarta.

Siska, A.P.P., (2012). Karir dan Pekerjaan Di Masa Dewasa Awal Dan Dewasa Madya. Majalah Ilmiah Informatika Vol.3 No.3, Sept. 2012,. Fakultas Psikologi Universitas AKI Semarang.

Sopiah (2008). Perilaku Organisasi, Andi, , Andi, Yogyakarta.

Sugiyono (2008). Metode Penelitian Kuantitatif, Kualitatif dan R\&D. Bandung: Alfabeta

Sugiyono (2013). Metode Penelitian Kuantitatif, Kualitatif dan RED. Bandung: Alfabeta.CV

Sugiyono (2016). Metode Penelitian Kuantitatif, Kualitatif, dan R\&D. Bandung: Alfabeta

Sulianti Diana, K.L.T (2011). Pengaruh Komitmen Organisasional dan Kepuasan Kerja Terhadap Kinerja Karyawan PT. Perkebunan Nusantara III di Sumatera Utara. Jurnal Fakultas Ekonomi, Universitas Jember. 
Tischler, L. (2002). Linking Emotional Intelligence, Spirituality and Workplace Performance: Definitions, Models and Ideas for Research. Journal of Managerial Psychology. 17 (3): 203.

Wainaina, Iravo and Waititu (2014). Workplace spirituality as a determinant of organizational commitment amongst academic staff in the private and public universities in Kenya. Internatioanl journal of academic research in business and social sciences. Desember 2014, Vol. 4, No. 12. ISSN : 2222-6990

Wirawan, (2013). Kepemimpinan: Teori, Perilaku Organisasi, Aplikasi dan Penelitian. Jakarta: Raja Grafindo Persada

Wikipedia (2017). Sumber Daya Manusia. Diakses pada 9 september 2017. Diakses di https://id.wikipedia.org/wiki/Sumber_daya_manusia

Zulkarnain dan Sherry (2014). Peranan Komitmen Organisasi dan Employee Engagment terhadap Kesiapan Karyawan untuk Berubah. Jurnal Psikologi Vol. 41 No. 1; Universitas Sumatera Utara.

Zohar, Danah, dan Marshal, Ian, (2005). Spiritual Capital: Memberdayakan SQ di Dunia Bisnis.Terjemahan Helmi Mustofa. Jakarta: Mizan Pustaka 